\title{
Molten Carbonate Fuel Cell Product Design Improvement Tracer Tests
}

\author{
Topical Report \\ December 20, 1995 - December 20, 1996
}

\section{REEIVEO \\ SEP 221998 \\ OSTI}

Work Performed Under Contract No.: DE-FC21-95MC31184

For

U.S. Department of Energy

Office of Fossil Energy

Federal Energy Technology Center

P.O. Box 880

Morgantown, West Virginia 26507-0880

By

Energy Research Corporation

3 Great Pasture Road

Danbury, Connecticut 06813 


\section{Disclaimer}

This report was prepared as an account of work sponsored by an agency of the United States Government. Neither the United States Government nor any agency thereof, nor any of their employees, makes any warranty, express or implied, or assumes any legal liability or responsibility for the accuracy, completeness, or usefulness of any information, apparatus, product, or process disclosed, or represents that its use would not infringe privately owned rights. Reference herein to any specific commercial product, process, or service by trade name, trademark, manufacturer, or otherwise does not necessarily constitute or imply its endorsement, recommendation, or favoring by the United States Government or any agency thereof. The views and opinions of authors expressed herein do not necessarily state or reflect those of the United States Government or any agency thereof. 


\section{DISCLAIMER}

Portions of this document may be illegible electronic image products. Images are produced from the best available original document. 


\section{ACKNOWLEDGEMENT}

The activities reported here were sponsored by DOE/METC and DOD/DARPA and cost-shared by the ERC team. The key ERC team members include: two of its subsidiaries FCMC and FCE, Fluor-Daniel, Jacobs Applied Technology, and Fuel Cell Commercialization Group. Numerous employees of ERC and these organizations have contributed to this project. The role of each of the organizations and its principal project leader are: Energy Research Corporation (ERC), R\&D arm coordinating the effort under all program areas, Fuel Cell Engineering (FCE), subsidiary of ERC, for product definition oversight and overall plant construction management and customer service (D. Glenn), Fuel Cell Manufacturing Corporation (FCMC), another subsidiary of ERC, responsible for manufacturing process development and stack module fabrication (C. Bentley), Fluor Daniel, Inc. (FDI), Irvine, CA, assisting FCE in power plant design (B. Fugard), Jacobs Applied Technology (JAT), Orangeburg, SC, consulting in assembly and packaging of fuel cell stack and BOP modules (H. Rast).

Energy Research Corporation, the overall project coordinator, and its subsidiaries provided the lead role in the execution of program tasks. The program activities are organized under seven tasks. The task leaders are, P. Voyentzie (ERC), D. Glenn (FCE), A. Kush (FCE), C. Bentley (FCMC), P. Patel (ERC), G. Carlson (ERC), and C. Yuh (ERC).

Interactions and guidance of DOE/METC Technical Representative Thomas George and R. Rosenfeld of DOD/DARPA are acknowledged. 


\section{INTRODUCTION}

The carbonate fuel cell promises highly efficient, cost-effective, environmentally superior power generation from pipeline natural gas, coal gas, biogas, and other gaseous and liquid fuels. ERC has been engaged in the development of this unique technology since the late 1970s, primarily focusing on the development of the Direct Fuel Cell (DFC) technology [1-6] pioneered by ERC. The DFC design incorporates the unique internal reforming feature which allows utilization of a hydrocarbon fuel directly in the fuel cell without requiring any external reforming reactor and associated heat exchange equipment. This approach provides upgrading of waste heat to chemical energy; thereby, it contributes to higher overall efficiency for conversion of fuel energy to electricity with low levels of environmental emissions. Among the internal reforming options, ERC has selected the Indirect Internal Reforming (IIR) - Direct Internal Reforming (DIR) combination as its baseline design.

ERC plans to offer commercial DFC power plants in various sizes, initially focusing on the MW-scale units. The plan is to offer standardized, packaged MW-scale DFC power plants operating on natural gas or other hydrocarbon-containing fuels for commercial sale by the end of the decade. These power plants, which can be shop-fabricated and sited near the user, are ideally suited for distributed generation, industrial cogeneration, and uninterrupted power for military bases. After gaining experience from the early MW-scale power plants, and with maturing of the technology, ERC expects to introduce larger power plants operating on natural gas and/or coal gas or other fuels in the beginning of the 21 st century.

ERC has completed a technology program for product design verification, a predecessor of the current program, where the power plant design as well as the technology development were carried out to support a full-size field demonstration. These activities culminated in 130 $\mathrm{kW}$ stack tests in ERC's subscale power plant, subscale stack tests in utility and industrial sites around the world, and a $1.8 \mathrm{MW}$ power plant design for demonstration at a utility site. The design and procurement were completed and testing of this world's largest multi-megawatt advanced fuel cell demonstration plant is in progress. Built on these advances, ERC launched the product development phase, sponsored by government and private-sector cost-share, leading to technology and system optimization for cost reduction, commercial design development, and system demonstration. Accomplishment highlights of the second budget period are discussed in this paper.

\section{OBJECTIVES AND APPROACH}

This program is designed to advance the carbonate fuel cell technology from the power plant demonstration to the commercial design in an approximately five-year period. The specific objectives selected to attain the overall program goal are: 
- Define power plant requirements and specifications,

- Establish the design for a multifuel, low-cost, modular, market-responsive power plant,

- Resolve power plant manufacturing issues and define the design for the commercial-scale manufacturing facility,

- Define the stack and balance-of-plant (BOP) equipment packaging arrangement and module designs,

- Acquire capability to support developmental testing of stacks and critical BOP equipment to prepare for commercial design, and

- Resolve stack and BOP equipment technology issues, and design, build, and field test a modular prototype power plant to demonstrate readiness for commercial entry.

A seven-task program, dedicated to attaining objective(s) in the areas noted above, was initiated in December 1994.

\section{PROJECT DESCRIPTION}

ERC is currently in the second year of the five year program for development and demonstration of a MW-class power plant supported by DOE/METC, with additional funding from DOD/DARPA and the ERC Team. Figure 1 shows key program elements (shaded area) and their interrelationships. The product definition and specification have been derived with input from potential users, including the Fuel Cell Commercialization Group (FCCG). Detailed power plant system and packaging designs are being developed using stack and BOP development results. A MW-scale prototype modular power plant representative of an early production unit (EPU) is planned to be constructed and tested. Based on the experience and data generated in the current program, ERC also plans to acquire manufacturing capability for EPUs through expansion of the existing Torrington production facility. 


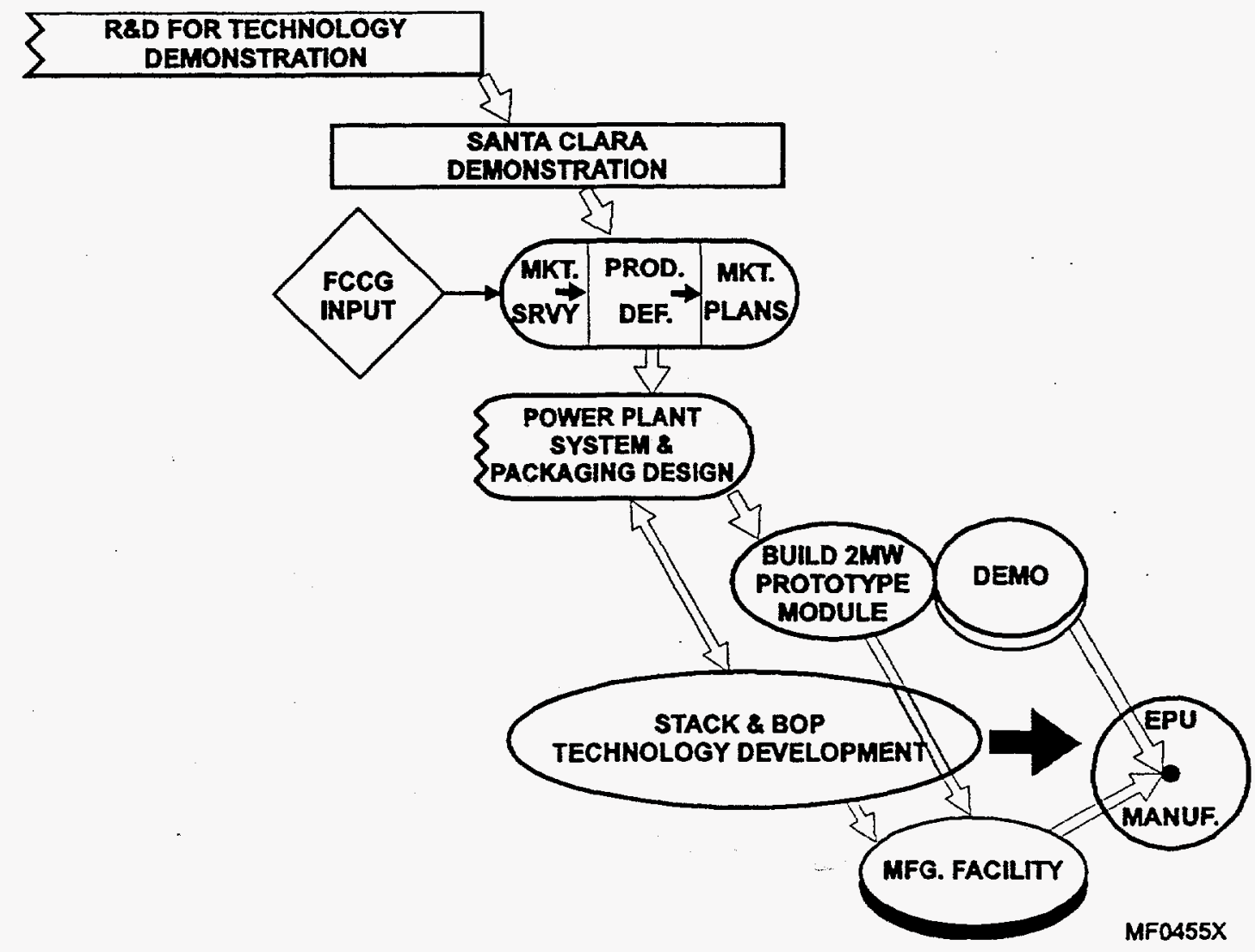

Figure 1. EFFORT AND INTERACTION OF KEY PROJECT ELEMENTS:

The Program will Result in the Early Production Commercial Product Design

The project team has been assembled to supplement all relevant expertise required for product design, improvement, verifications, and marketing. The team consists of:

Energy Research Corporation (ERC), R\&D arm focusing on market-entry product improvement, coordinating the effort under all program areas;

Fuel Cell Engineering (FCE), a subsidiary of ERC, concentrating on product definition oversight and overall plant construction management and customer service;

Fuel Cell Manufacturing Corporation (FCMC), another subsidiary of ERC, focusing on manufacturing process development and stack module fabrication;

Fluor Daniel Inc. (FDI), Irvine, CA, assisting FCE in power plant and manufacturing plant designs; 
Jacobs Applied Technology (JAT), Orangeburg, SC, assisting in assembly and packaging of fuel cell stacks and BOP modules;

Fuel Cell Commercialization Group (FCCG), Washington, D.C., a group of potential buyers of early production units, collaborating with FCE in product definition, system design, utility system planning and information distribution;

Motoren-und Turbinen-Union (MTU), Germany, an affiliate of Daimler Benz, conducting parallel stack technology development focusing on endurance, cost reduction, and cogeneration applications.

\section{RESULTS/ACCOMPLISHMENTS}

ERC is developing the detailed design of the commercial entry MW-class power plant. In collaboration with the FCCG, the product requirements and specifications have been derived. The planned baseline power plant is rated at $2.85 \mathrm{MW}$ on natural gas and has a heat rate of 6.22 x $10^{6} \mathrm{~J} / \mathrm{kWh}(5900 \mathrm{Btu} / \mathrm{kWh} ; 58 \% \mathrm{LHV})$. Additional optional features will be available to include non-standard site conditions and other fuels. The FCCG members are potential buyers of the EPUs. A model EPU purchase contract has been developed with the FCCG Board of Directors and first Letter of Intent for an EPU purchase has been obtained.

In parallel, the baseline product design has progressed to the final design phase in collaboration with FDI. The preliminary product design, which also included parametric optimization, major component vendor interaction, and cost estimation, has been completed during the past year. The power plant approach consists of several factory-constructed trucktransportable modules. A computer-generated power plant layout is shown in Figure 2. The proposed power plant is expected to have a gross output of $3.03 \mathrm{MW}$, providing net $2.85 \mathrm{MW}$ AC. The parasitic power loss is approximately $6 \%$, of which, inverter, step-up transformer, BOP motors, and miscellaneous loads consume $2 \%, 1 \%, 2 \%$, and $1 \%$, respectively. 


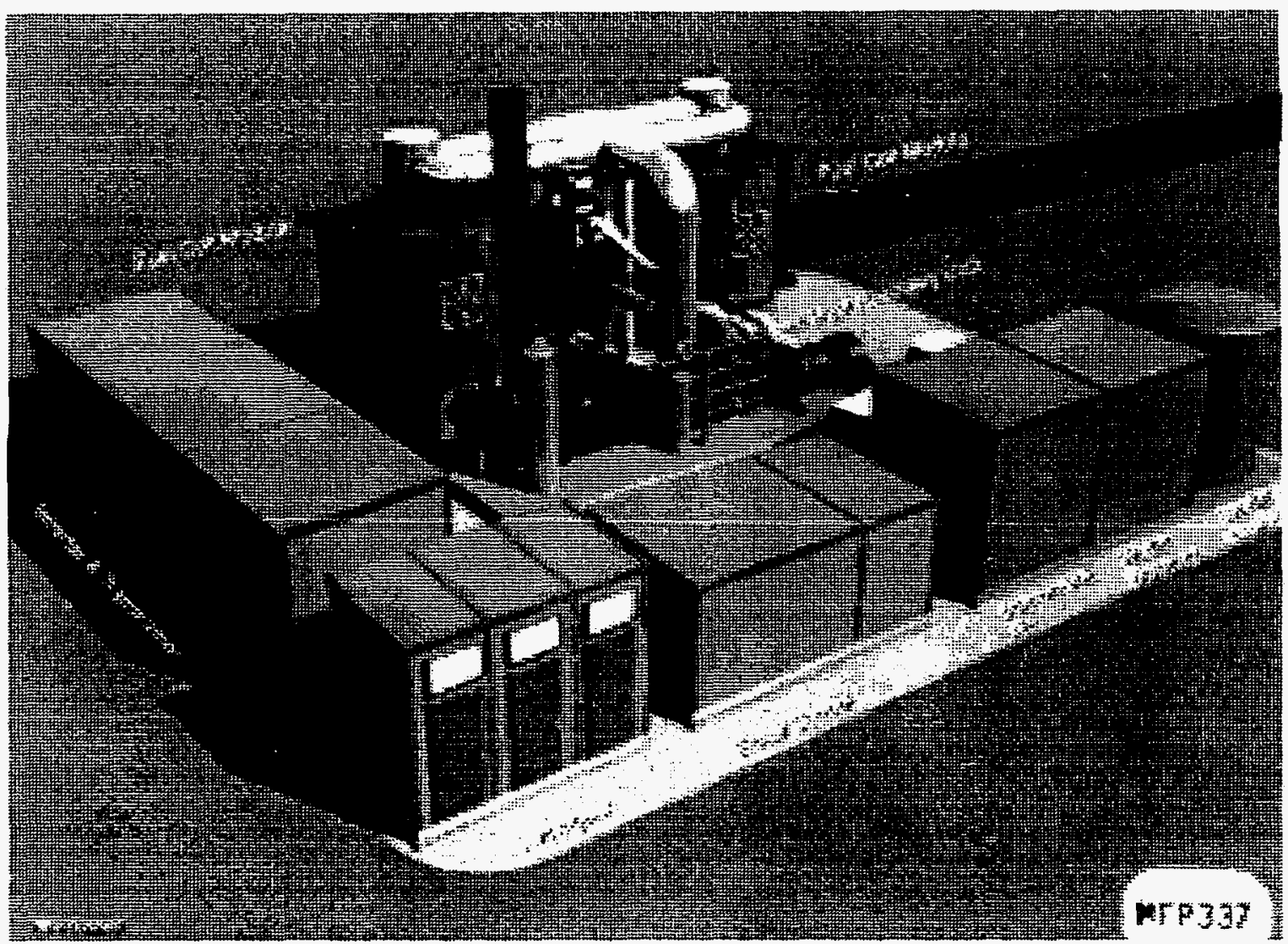

Figure 2. BASELINE COMMERCIAL POWER PLANT LAYOUT: The 2.85 MW Power Plant Design has Progressed to the Final Design Phase

Standard conditions for ERCs power plant design include a $15^{\circ} \mathrm{C}$ ambient temperature, $60 \%$ relative humidity, and sea level elevation. The effects of ambient temperature from $-20^{\circ} \mathrm{C}$ to $43^{\circ} \mathrm{C}$, relative humidity from 0 to $100 \%$, and elevation up to $1500 \mathrm{~m}$ on the power plant rating have been investigated (Figures 3 and 4). The net maximum impact on plant rating was found to be $-3 \%$. This is extremely low when compared with the state-of-the-art turbine-based power plants which may suffer over $10 \%$ capacity loss with change of ambient conditions. The DFC power plant rating is also essentially unaffected for fuel heating value change from $33.5 \times 10^{6}$ $\mathrm{J} / \mathrm{m}^{3}$ to $37.2 \times 10^{6} \mathrm{~J} / \mathrm{m}^{3}(900 \mathrm{Btu} / \mathrm{scf}$ to $1,000 \mathrm{Btu} / \mathrm{scf}$ ). This heating value range covers most of the U.S. pipeline natural gas. Also, a preliminary Reliability and Maintainability (RAM) assessment of the power plant was made using the UNIRAM software and assessment methodology consistent with the analysis described in the published EPRI Report TR-101107. The RAM study concluded that the base case commercial fuel cell power plant is expected to achieve an availability in excess of $95 \%$, with a one week per year scheduled outage period. Additionally, the criticality analysis demonstrated that the BOP equipment is reliable and available. 


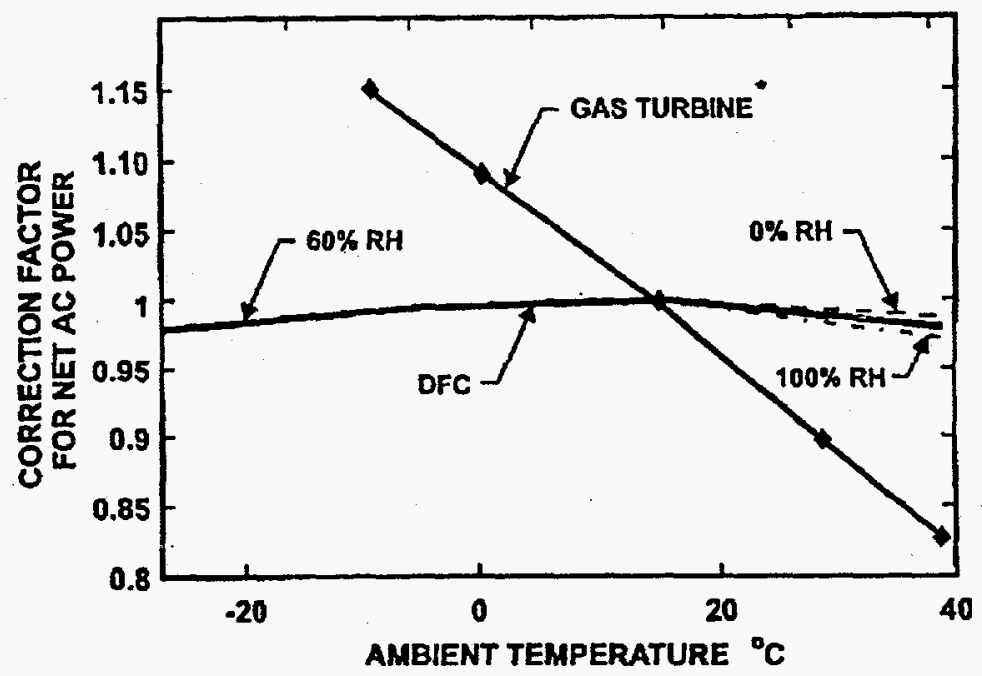

*Source: Gas Turbine Performance - New Application and Test Correction Curves, Presented at the Intemational Gas Turbine and Aeroengine Congress and Exposition, Houston, Texas, June 5-8, 1995

Figure 3. DFC POWER PLANT CORRECTION FACTORS FOR AMBIENT TEMPERATURE AND RELATIVE HUMIDITY:

DFC Output is not Sensitive to Ambient Temperature and Humidity Changes

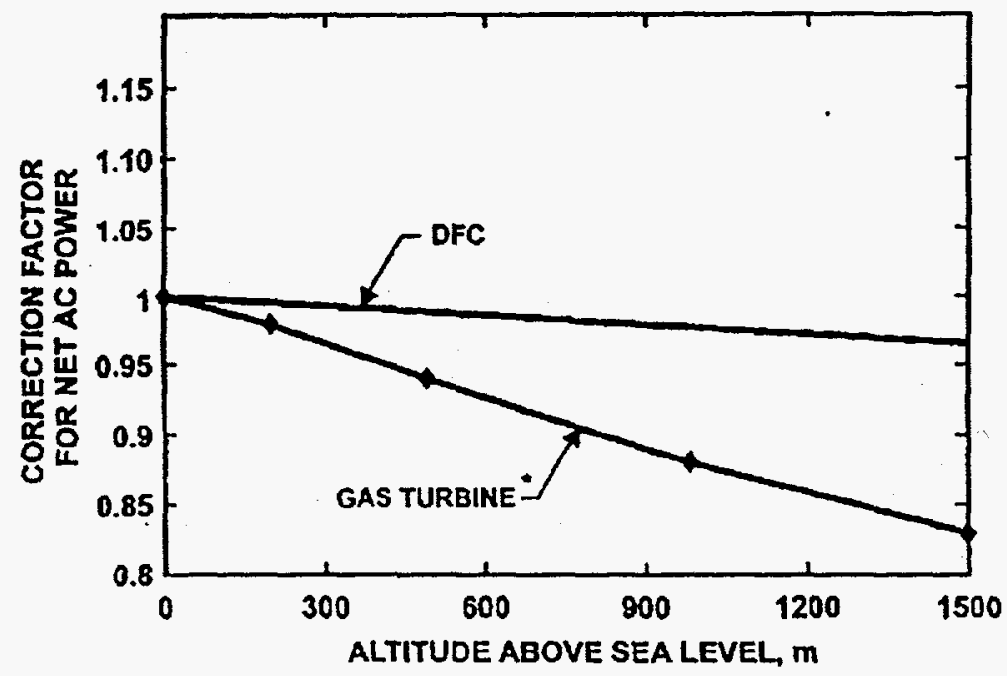

* Source: Gas Turbine Performance New Application and Test Correction Curves, Presented at the Intemational Gas Turbine and Aeroengine Congress and Exposition, Houston, Texas, June 5-8, 1995

Figure 4. DFC POWER PLANT CORRECTION FACTORS FOR ALTITUDES: Altitude Effect on DFC is Small 
In the preliminary design development phase, the $2.85 \mathrm{MW}$ DFC plant dynamic simulation model was developed to evaluate transient behavior, equipment design parameters, and control strategies. The model used Aspen Tech's Speedup program to integrate the fuel cell and BOP equipment models for simulating appropriate start-up, steady state, shutdown, load transient conditions, and system upsets to gain operating insights. As an example, the dynamic simulation results shown in Figure 5 indicate that the output power can be ramped from 25\% to $100 \%$ of the rated load in less than 10 minutes, a feature desired by some power plant buyers. The results of the dynamic simulations will be incorporated into the plant design as it evolves to the final stage.

An equipment list was prepared and major equipment vendors were contacted with equipment specifications for design and budgetary cost estimates. A cost estimate based on budgetary quotes from vendors indicated that the capital cost of $\$ 1,250 / \mathrm{kW}$ (1995 dollars) is achievable for the matured commercial product. This was further confirmed by an independent stochastic review of design assumptions and cost models. Variances of design assumptions and cost elements were defined and a Monte Carlo simulation was conducted to identify power plant cost profile. It was observed that the probability of attaining the cost goal of $<\$ 1250 / \mathrm{kW}$ is better than $75 \%$ (Figure 6 ).

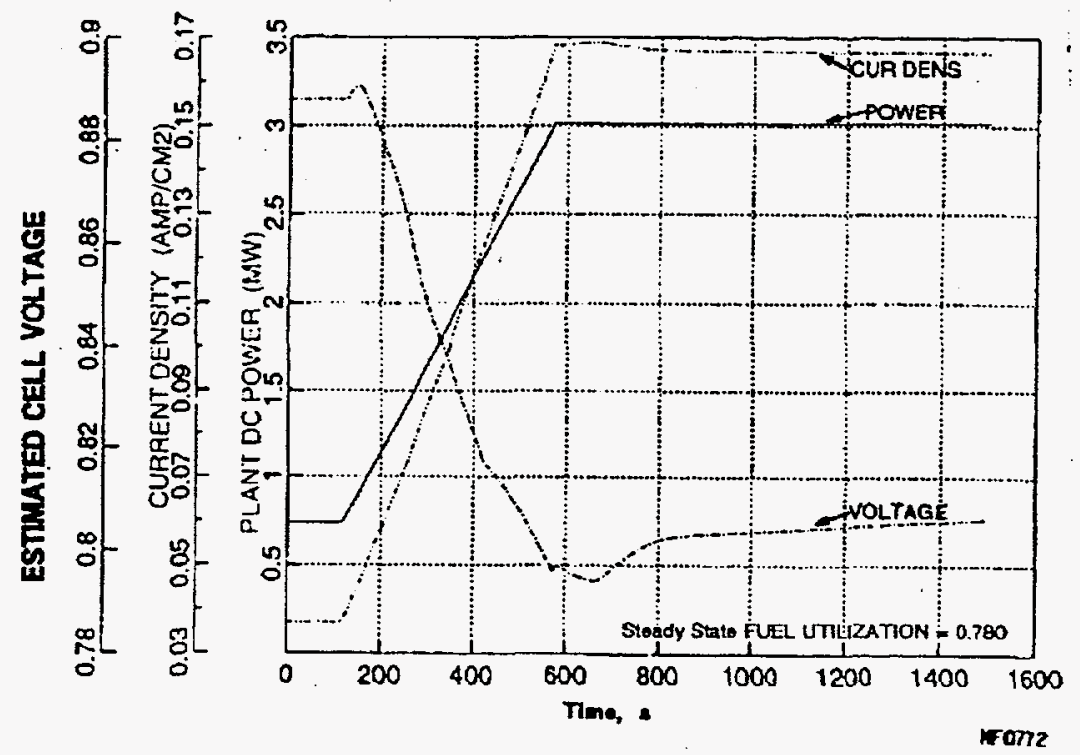

Figure 5. POWER RAMP FROM QUARTER TO FULL LOAD: Rated Power can be Achieved from a 1/4 Rated Load in 10 Minutes 


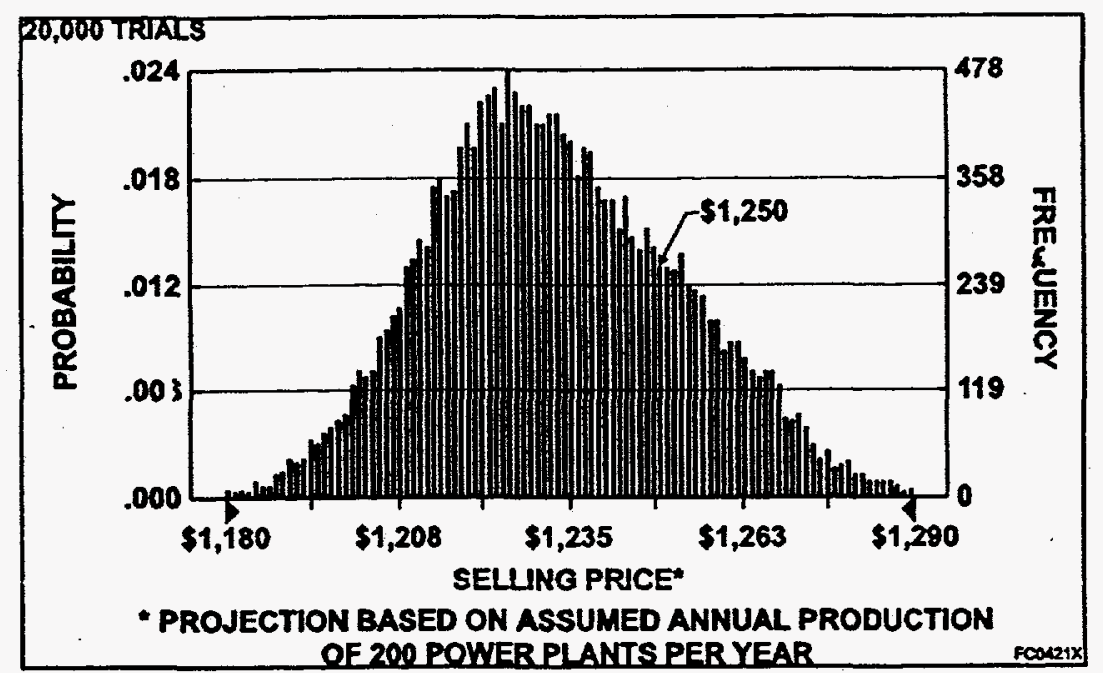

FC0421X

Figure 6. TOTAL POWER PLANT MANUFACTURING COST FORECAST (\$/kW): Probability of Meeting the Product Cost Goal of $\$ 1250 / \mathrm{kW}(1995 \$)$ is Better than $75 \%$

The power plant operating and maintenance costs have been analyzed (Table 1). Because the power plant is expected to operate automatically, the fixed and variable operating cost is projected to be low, -4 mills $/ \mathrm{kWh}$. Fuel cell replacement cost is projected to be 7 mills $/ \mathrm{kWh}$, and the capital carrying charge is estimated to be $16 \mathrm{mills} / \mathrm{kWh}$. Assuming fuel cost to be $\$ 2.32 /\left(10^{9} \mathrm{~J}\right)(\$ 2.45 / \mathrm{MM} \mathrm{Btu})$, the 30 -year levelized cost-of-electricity (COE) is projected to be about 4 cents.

Table 1. 30-YEAR LEVELIZED O\&M COSTS:.

DFC Cost-of-Electricity is Projected to be $\sim 4$ Cents

\begin{tabular}{|c|c|}
\hline Tenent & (Constint 19958$)$ \\
\hline Installed Cost & 16 \\
\hline Fixed & 1 \\
\hline Variable & 4 \\
\hline Fuel @ \$2.45/MMBtu & 14 \\
\hline Stack Replacement & 7 \\
\hline COE & 42 \\
\hline
\end{tabular}

As discussed earlier, the ERC standard product can provide several optional features such as grid-independent operation. Another optional configuration is dual fuel operation, using natural gas or the DOD logistic fuels (JP-8 and diesel), for fixed base power plant applications. The logistic fuel operation requires a front-end fuel processor to convert logistic fuels to fuel cell compatible feed stream. The diesel and jet fuel processing design information is being developed at ERC in parallel. Originally, under a Navy SBIR program, ERC tested a labscale carbonate 
fuel cell stack on a model diesel-like fuel (Exxsol) in 1991-93 using an adiabatic prereformer to convert liquid fuel to methane. More recently under the DARPA/NASA sponsored program, ERC verified a $32 \mathrm{~kW}$ size stack operation on jet fuel (JP-8) and diesel (DF-2) in system integrated tests, employing ERC's diesel-to-methane fuel processing approach. The stack was also tested at landfill gas simulated system condition. The stack performance comparison on different fuel systems is shown in Figure 7. The cathode gas composition for each fuel test was simulated to represent the system conditions. Stack operability on multiple fuels was verified. The stack performance at different conditions indicates that only a slight output power derating $(\sim 5 \%)$ of the baseline $2.85 \mathrm{MW}$ product is expected for DOD fuels and landfill gas operations. A $3 \mathrm{MW}$ logistic fuel preprocessor design will be defined based on the $32 \mathrm{~kW}$ size breadboard fuel preprocessor experience. The diesel fuel processor as available from this parallel effort could be interfaced with the baseline natural gas power plant design so that the DFC plant can be used for the dual fuel (diesel and pipeline natural gas) DOD application.

To reduce cell costs and achieve optimum packaging of stacks in the truck-transportable module, the cell area was scaled-up from $6000 \mathrm{~cm}^{2}(2 \mathrm{ft} \times 3 \mathrm{ft})$ to $9000 \mathrm{~cm}^{2}(2 \mathrm{ft} \times 4 \mathrm{ft})$ nominal size. The capital equipment required for the manufacture of the large area repeating cell components was commissioned. The equipment list includes a pneumatic trim sizing press, a precision sizing machine, and a large area hydraulic press (shown in Figure 8). In parallel with scaleup, efforts were focused to establish process and/or equipment specifications to improve component tolerance and/or reproducibility. As an example, the new press was specified to produce parts better than dimensional tolerance specifications.

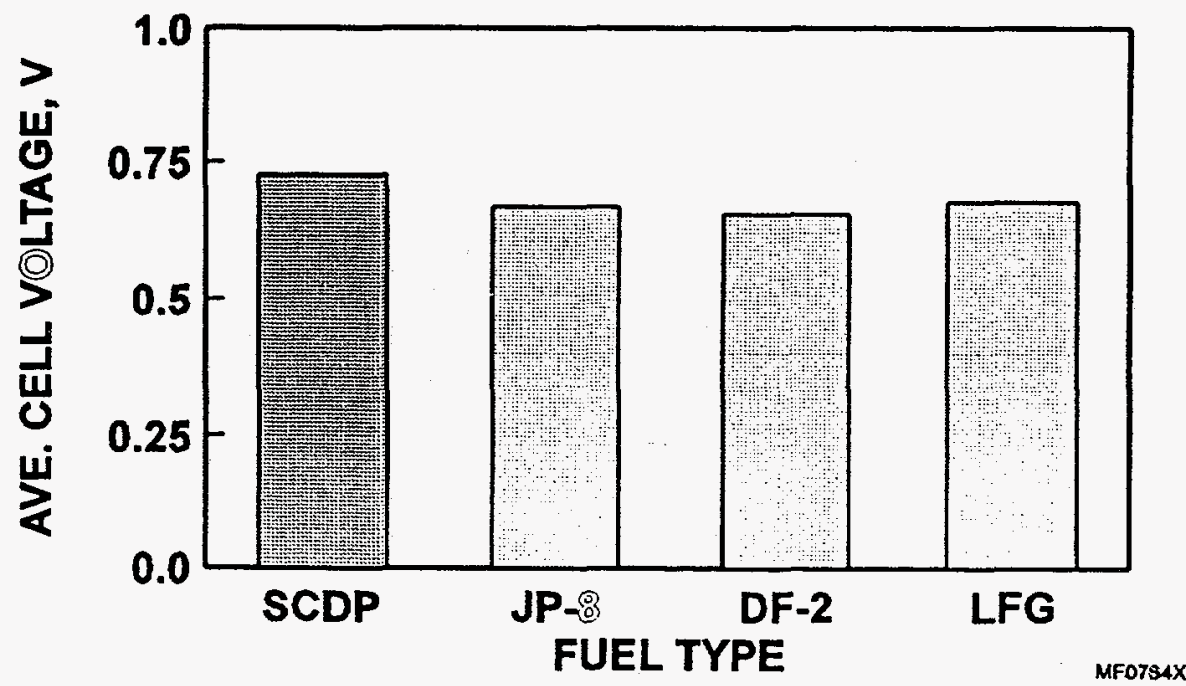

Figure 7. $30 \mathrm{~kW}$ STACK PERFORMANCE COMPARISON ON DIFFERENT FUELS $\left(131 \mathrm{~mA} / \mathrm{cm}^{2}, 70 \%\right.$ Fuel Util., $\left.656^{\circ} \mathrm{C}\right)$ :

Less than 5\% Derating of Product is Expected for the Military Fuels 


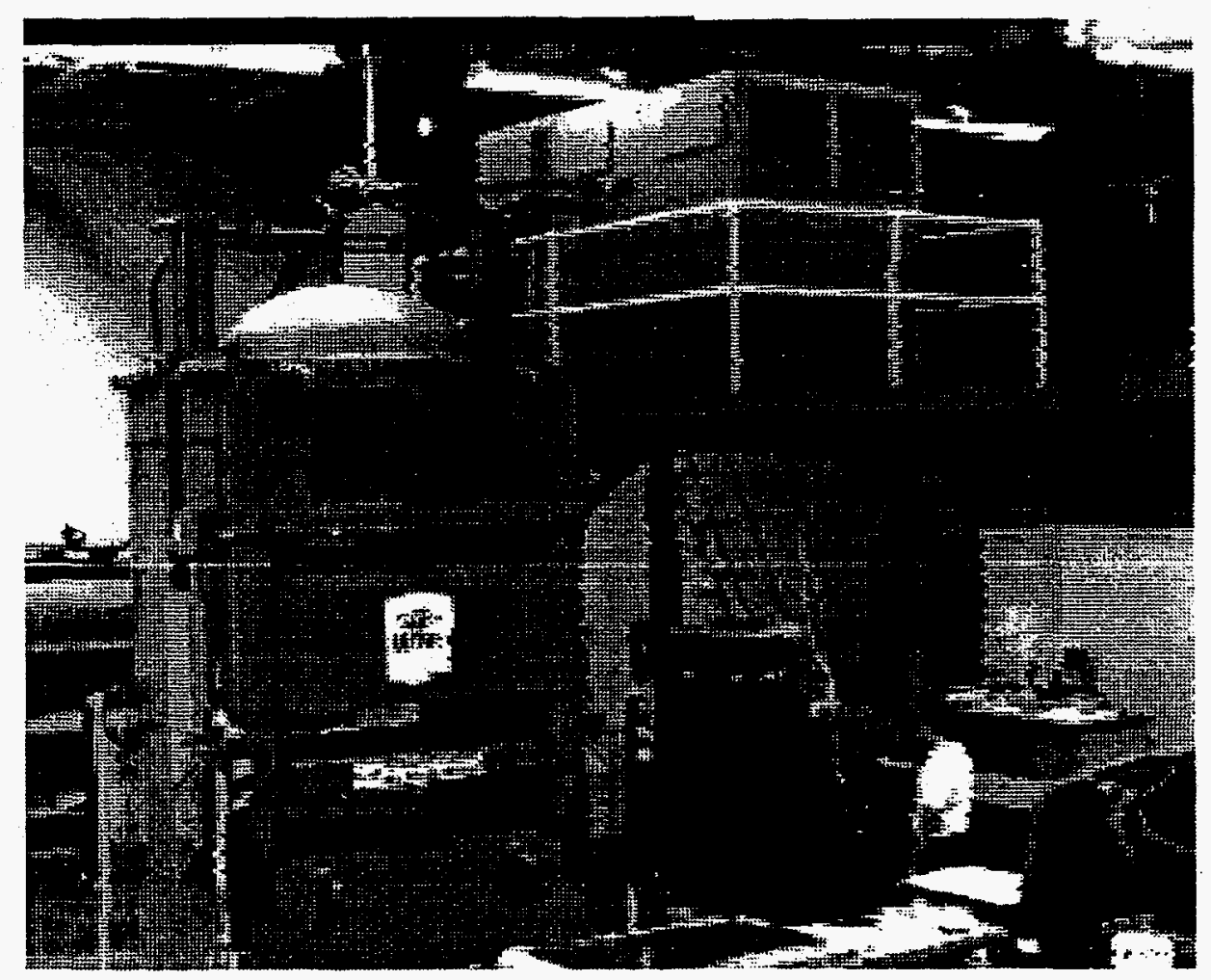

Figure 8. LARGE AREA HYDRAULIC PRESS:

Successfully Commissioned and Used for Managing Tolerance of $9000 \mathrm{~cm}^{2}$ Cell Packages

An advanced bipolar plate design, eliminating an expensive vendor processing operation, has been developed. A low-cost wet seal corrosion protection process developed by MTU in the parallel technology effort was successfully scaled-up and implemented in the full-area bipolar plate. The 11,000 hour corrosion result of this new low-cost process, compared with the baseline design in Figure 9, indicates no stability issue. These bipolar plate design modifications have resulted in approximately $40 \%$ cost reduction. Large area $\left(9000 \mathrm{~cm}^{2}\right)$ anode, cathode and matrix components were manufactured using the newly commissioned equipment. A photograph of the $9000 \mathrm{~cm}^{2}$ cell package produced is shown in Figure 10. An automated final cell package quality control measurement system has been developed. The initial $9000 \mathrm{~cm}^{2}$ cell area packages showed $35 \%$ improvement in thickness tolerance over the previous $\left(6000 \mathrm{~cm}^{2}\right.$ cell) experience.

Efforts were also focused on process optimization for increased productivity as well as overall quality improvement. Anode tape casting is fully developed and belt speed optimization and automatic blade height adjustment designs were implemented to improve production rates as well as dimensional tolerance. Matrix tape cast process optimization is also in progress. These efforts were successful in reducing tape slurry preparation time by a factor of thirty, and casting time by a factor of three. In addition to production rate improvement, a $30 \%$ reduction in matrix green tape thickness tolerance was achieved through tape caster improvements. 

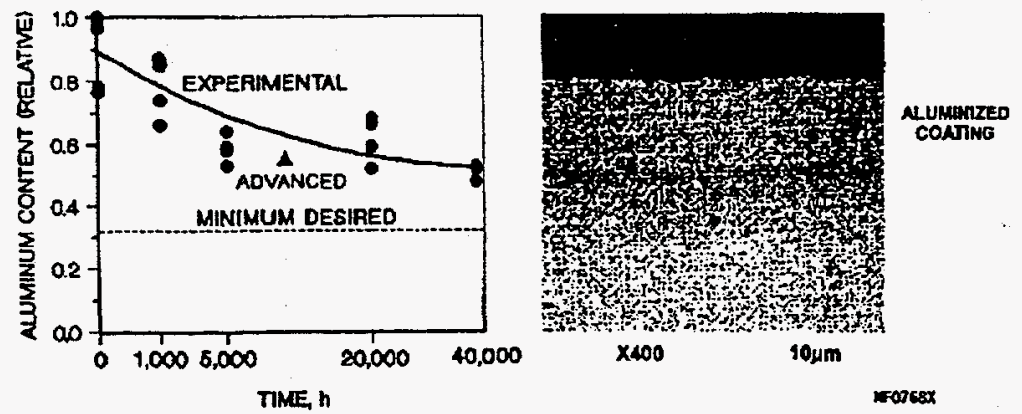

Figure 9. WET SEAL CORROSION CHARACTERIZATION:

The Baseline Design ( $\bullet$ ) Expected to Last for 40,000 hours; the Advanced Low-Cost Design ( 1 ) also Appears to be Stable

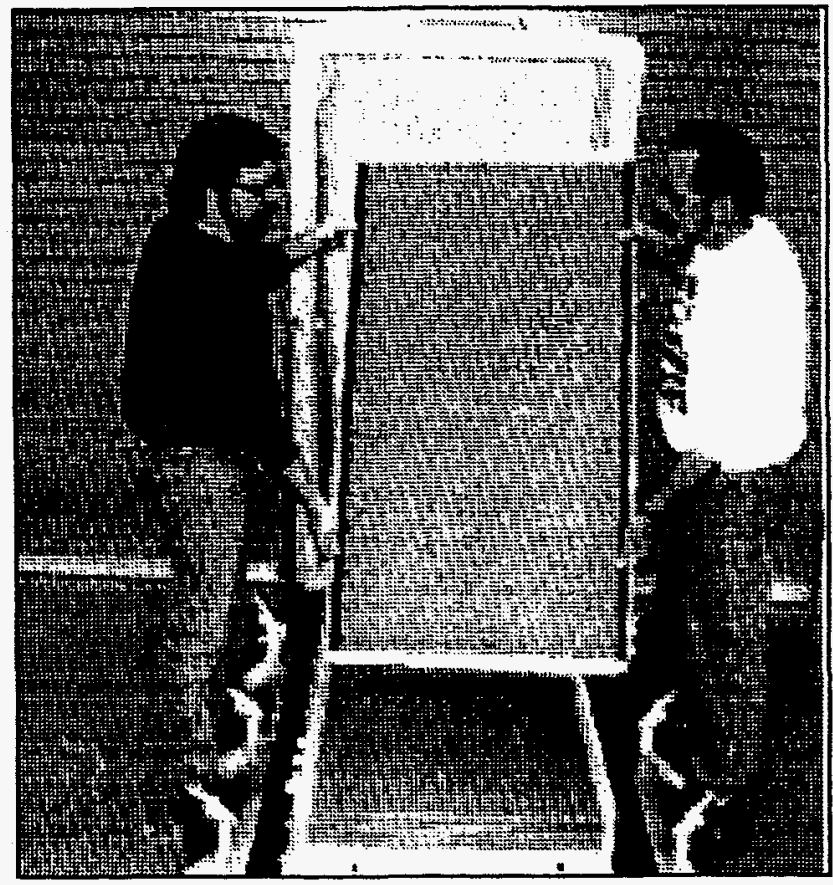

Figure 10. FULL-AREA CELL PACKAGE:

The $9000 \mathrm{~cm}^{2}$ Cell Components Fabricated at FCMC to Verify Scaleup 
The indirect internal reformer unit weight has been reduced by $60 \%$ over the 1995 design. The first stack test using this lightweight reformer design and the scaled $9000 \mathrm{~cm}^{2}$ cell components (a photograph of the stack is shown in Figure 11) has been completed. The 10-cell IIR-DIR stack was tested in conjunction with an internally insulated enclosure. Performance of this large cell area stack is compared with previous $6000 \mathrm{~cm}^{2}$ area lightweight and Santa Clara type heavy designs in Figure 12. The results indicate that the scaleup of the lightweight component has been achieved without any performance penalty. Cell temperature profile corresponding to $160 \mathrm{~mA} / \mathrm{cm}^{2}$ operation is shown in Figure 13. The results show that the large area DFC stack has achieved an excellent temperature uniformity.

Prior to building the full-height stack, a full-size stack simulator has been fabricated for verification of assembly procedures, designs of the manifolds, and gas flow distribution design. A photograph of the simulator is shown in Figure 14. A gas flow model and the simulator experiments were utilized to define tall stack manifold designs to achieve cell-to-cell uniform flow distribution. Less than $2 \%$ flow variation between cells for fuel as well as oxidant is projected. A fuel cell module will contain four full-size stacks. The gas flow distribution system designs within the module were defined and the performances were verified in cold tests. The expected fuel flow variations between the stacks in a module are shown in Figure 15; fuel flow variations are expected to be less than $1 \%$. ERC has now completed mechanical construction of a $400 \mathrm{~kW}$ subscale power plant which will be used to verify the performance of the full height stack and BOP equipment in system tests. A photograph of this facility is shown in Figure 16. This subscale power plant is representative of the standard power plant design.

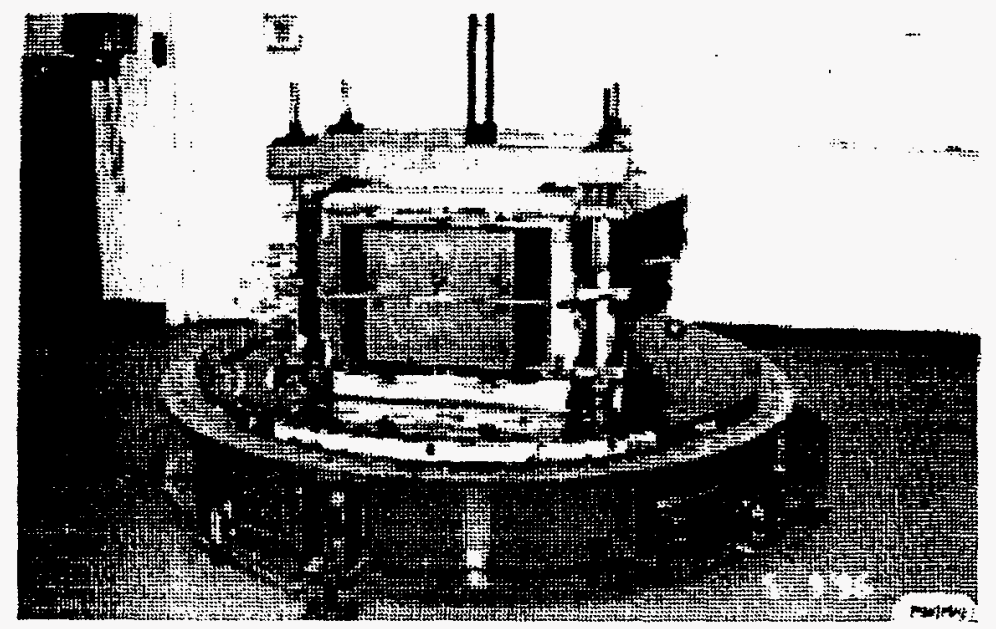

Figure 11. 10-CELL $9000 \mathrm{~cm}^{2}$ CELL AREA STACK: Stack Module Compatible Lightweight Stack Hardware Design Verifier 


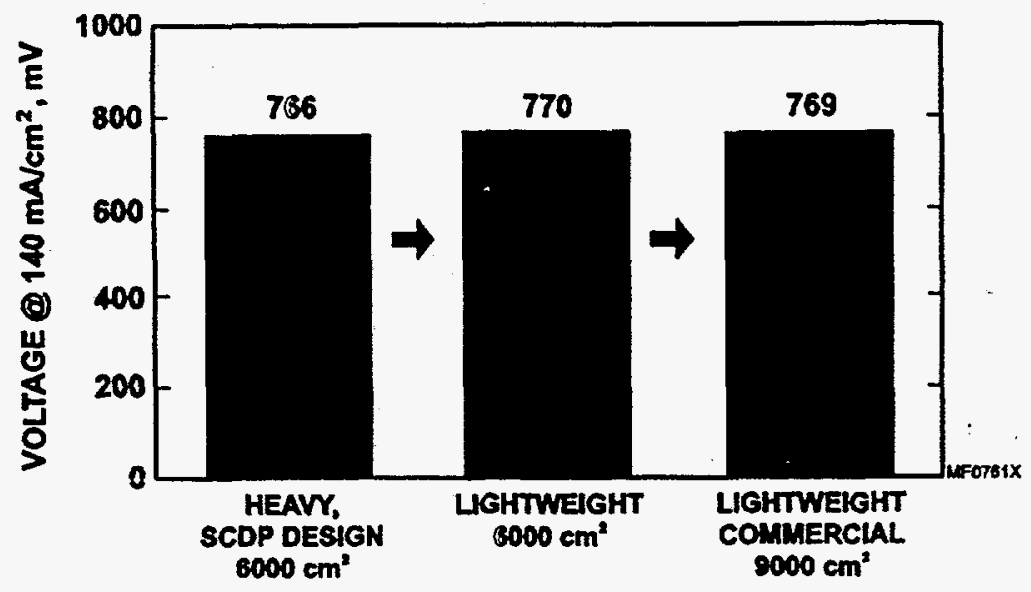

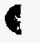

Figure 12. LIGHTWEIGHT LARGE CELL AREA STACK PERFORMANCE:

Cell Area Scale-up Achieved Without Performance Penalty

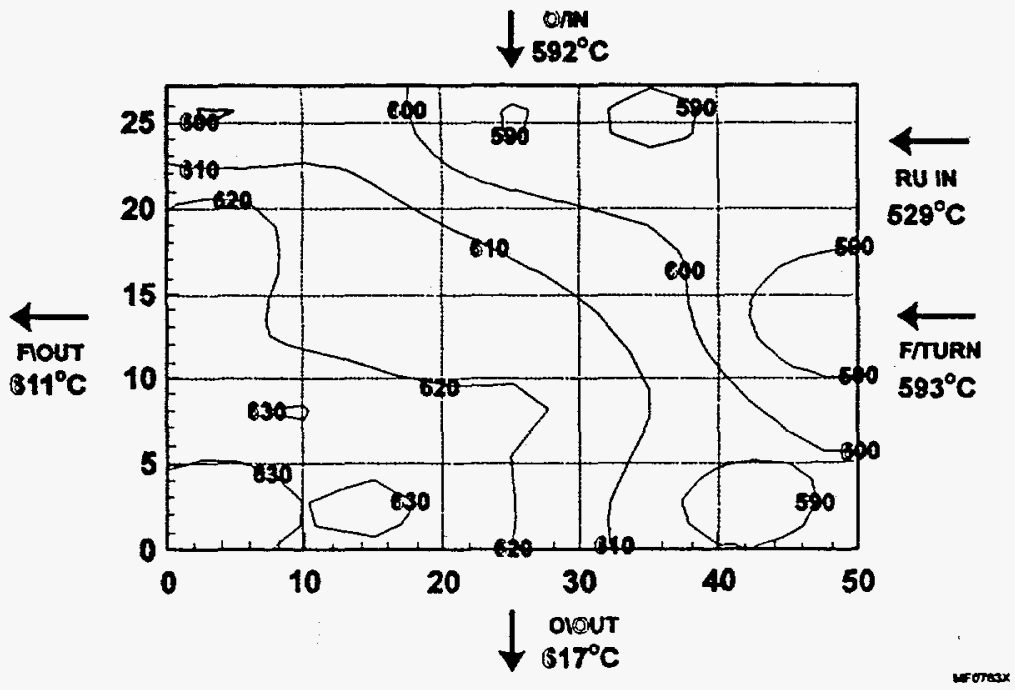

Figure 13. TEMPERATURE PROFILE AT $160 \mathrm{~mA} / \mathrm{cm}^{2}\left(9000 \mathrm{~cm}^{2}, 10\right.$-CELL DFC STACK):

Excellent Temperature Uniformity Achieved 


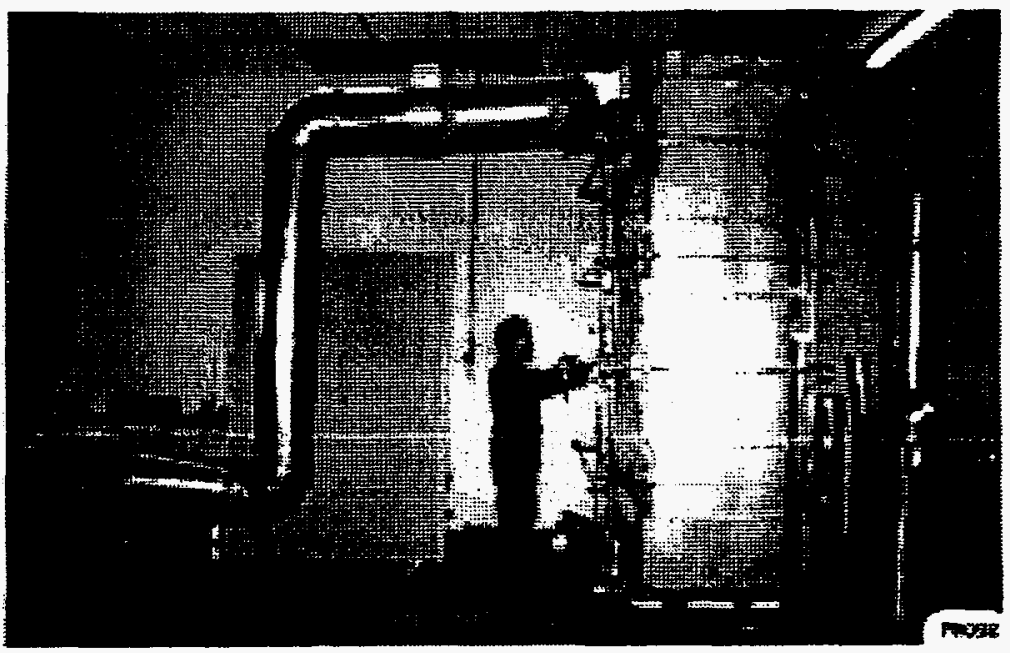

Figure 14. FULL-HEIGHT $9000 \mathrm{~cm}^{2}$ CELL AREA STACK SIMULATOR: Verified Stack Assembly Procedures and External Hardware Designs

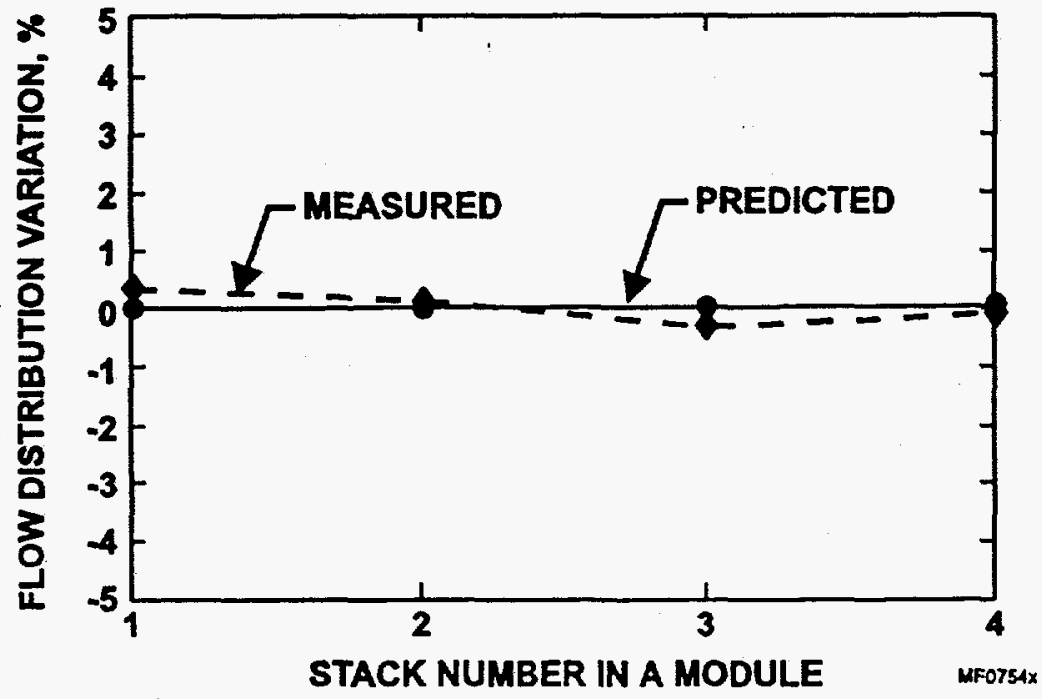

Figure 15. FUEL FLOW DISTRIBUTION BETWEEN STACKS IN A MODULE: $\sim 0.5 \%$ Flow Variations Expected

ERC is in the final design phase of the commercial power plant. Equipment packaging approaches and plant layout are being finalized. The cell area scaleup is completed. Components cost reduction, performance enhancement, and life extension efforts are on track. 
Future activities will focus on finalization of power plant design and verification of stack module enclosure and full-height stack designs.

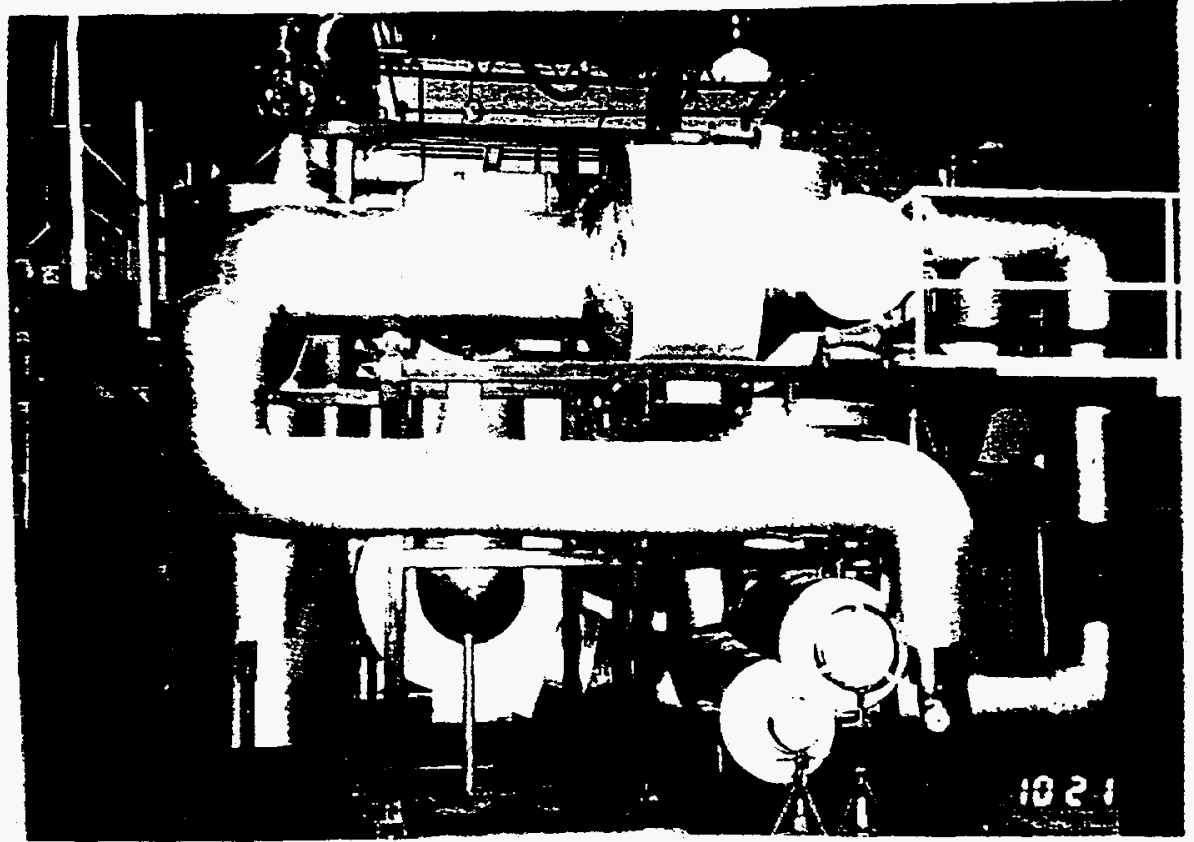

Figure 16. Photograph of the $400 \mathrm{~kW}$ :

Mechanical Construction and Assembly Completed

mo1722

\section{REFERENCES}

1. P. Patel, et al., "Internal Reforming for Natural Gas Fueled Molten Carbonate Fuel Cells", Final Report for the Period of May 1980 through June 1981 under GRI Contract No. 5080-344-0302.

2. P. Patel, et al., "Internal Reforming Natural Gas Fueled Carbonate Fuel Cell Stack", Final Report for the Period of February 1982 through December 1983, under GRI Contract No. 5081-244-0545.

3. L. Paetsch, et al., "Molten Carbonate Fuel Cell Development", DOE Contract No. DEAC03-76ET11304, Final Report, April, 1987.

4. M. Farooque, et al., "Development of Internal Reforming Carbonate Fuel Cell Stack Technology", Final Report for the Period of February 1988 through September 1990, under DOE Contract No. DE-AC21-87MC23274.

5. M. Farooque, et al., "Status of $120 \mathrm{~kW}$ Direct Fuel Cell Product Improvement and Testing", Proceedings of the Fuel Cell '94 Contractors Review Meeting, DOE/METC94/1010, August 1994.

6. M. Farooque, et al., "Simulated Coal Gas Fueled Carbonate Fuel Cell Power Plant System Verification", Final Report under Contract No. DE-AC21-90MC27168, March, 1995. 
TABLE 1. SUMMARY OF KEY ACTIVITIES PROPOSED FOR THE THIRD BUDGET PERIOD FUNDING

\begin{tabular}{|ll|l||}
\hline \multicolumn{2}{|c|}{ WORK ELEMENT } & \multicolumn{1}{c|}{ ACTIVITY SUMMARY } \\
\hline 1.0 & NEPA Information & $\begin{array}{l}\text { This activity has been essentially completed. 1996 } \\
\text { activity will focus on developing additional information } \\
\text { as may be needed. }\end{array}$ \\
\hline 2.0 & Product Definition and Planning & Preliminary market penetration plan will be ready. \\
\hline 3.0 & System Design and Analysis & $\begin{array}{l}\text { The baseline power plant final design will be } \\
\text { completed. The 1MW power plant configuration and } \\
\text { cost will be analyzed. The demonstration power plant } \\
\text { size will be selected. The design will be made ready } \\
\text { for procurement. }\end{array}$ \\
\hline 4.0 & $\begin{array}{l}\text { Manufacturing Process } \\
\text { Development }\end{array}$ & $\begin{array}{l}\text { Automatic cathode manufacturing line will be } \\
\text { commissioned. The bipolar manufacturing operations } \\
\text { will be streamlined. The tall stack assembly station } \\
\text { will be made ready. The stack materials recovery by } \\
\text { foundry remelting will be demonstrated. The quality } \\
\text { assurance manul will be updated incorporating audit } \\
\text { comments. } \\
\text { Total quality management will be inplemented at the } \\
\text { R\&D as well as the engineering facility. } \\
\text { Stack cost projection will be updated to reflect design } \\
\text { improvements. }\end{array}$ \\
\hline 5.0 & Assembly and Packaging & $\begin{array}{l}\text { Stack module design will be fine-tuned to incorporate } \\
\text { lessons learned for laboratory testing. The stack } \\
\text { module transporter design will be finalized. }\end{array}$ \\
\hline
\end{tabular}




\section{TABLE 1. SUMMARY OF KEY ACTIVITIES PROPOSED FOR THE THIRD BUDGET PERIOD FUNDING CONT'D}

\begin{tabular}{|c|c|c|}
\hline & WORK ELEMENT & ACTIVITY SUMMARY \\
\hline & $\begin{array}{l}\text { Technology Development, } \\
\text { Improvement, and Verification }\end{array}$ & $\begin{array}{l}\text { Active components and alternate electrolyte research } \\
\text { will continue to attain performance goal for early } \\
\text { commercial units. } \\
\text { Research activities will continue to attain increased } \\
\text { thermal cycling capability. } \\
\text { One piece anode current collector will be fabricated and } \\
\text { verified in full area stack tests. } \\
\text { Easy to assemble low-cost DIR catalyst will be } \\
\text { fabricated and verified. } \\
\text { Cell as well as low-cost stack auxiliary hardware } \\
\text { designs will be verified in } 5 \mathrm{~kW} \text { and } 20 \mathrm{~kW} \text { stack tests. } \\
\text { Full-height stack design will be evaluated in a } \\
\text { simulated test. } \\
\text { The baseline anode tail gas oxidizer design will be } \\
\text { verified in the subscale power plant tests. } \\
\text { Stack operation with the designed low steam-to-carbon } \\
\text { ratio will be verified in stack tests. }\end{array}$ \\
\hline
\end{tabular}

